\title{
PENGGUNAAN METODE TALKING STICK UNTUK MENINGKATKAN KAMPUAN HANDS-ON SISWA PADA MATERI BANGUN RUANG DI MI ISLAMIYAH DINOYO TERDEPAN LAMONGAN
}

\author{
Musa'adatul Fithriyah \\ Universitas Islam Lamongan, Lamongan, Indonesia \\ Email: saadahsyafie@gmail.com \\ Dina Fitriana \\ Universitas Islam Lamongan, Lamongan, Indonesia \\ Email:dinafitrianasg@gmail.com
}

\begin{abstract}
In the study of Building Space material in MI Islamiyah Dinoyo Front of the Lamongan there are problems including students who tend to be passive and the atmosphere in the classroom is less pleasant because teachers are more dominant using the lecture method with teaching center models so that the impact on learning outcomes is less than the maximum there are several results student learning is less than the specified KKM 75 amounting to $40 \%$ of the 24 total number of students. The purpose of this study is (1) Knowing the application of the talking stick method to improve hands-on ability (2) Knowing the increase in hands-on ability by using the talking stick method. The talking stick method is one of the learning methods carried out with the help of a stick, whoever holds the stick is obliged to answer questions from the teacher after students learn the main material taught by the teacher. Learning with the talking stick method is very suitable to be applied in elementary education (SD / MI), because in addition to training psychomotor and cognitive abilities, this learning creates a pleasant atmosphere and makes students active.
\end{abstract}


This talking stick method is very appropriate to be used in handson development. Researchers conducted using a qualitative approach to the type of classroom action research (CAR). Techniques used in data collection include: observation, interviews, documentation, test measurements, and field notes. The analysis used by researchers uses qualitative descriptive techniques. The sequence of research activities includes 4 stages including: (1) Planning, (2) Implementation, (3) Observation, and (4) Reflection. The results of the study obtained data that there is an increase in the hands-on ability of students learning Space Building material in class IV students from 2 cycles that have been run and can meet the performance indicators that have been set. In the implementation of the first cycle on the ability of Hands-On students from cycle I to cycle II also increased, namely in the first cycle the number of students who scored above KKM 75 as much as $60 \%$ of the total 24 students who attended and in the second cycle the number of students who got the value above the KKM reached $82 \%$ there was an increase of $25 \%$ from cycle I to cycle II with an average value of Hands-On ability in cycle I a number of 75.8 and in cycle II an average value of 80.16 an increase of 4.36 . Based on the results of the analysis of the research data it can be concluded that the use of the talking stick method can improve the ability of Hands-On material to Build Space and its implementation can run effectively and efficiently.

Keywords: hands-on, talking stick method, build space

\begin{abstract}
Abstrak
Pada pembelajaran materi Bangun Ruang di MI Islamiyah Dinoyo Terdepan Deket Lamongan terdapat permasalahan diantaranya terlihat siswa cenderung pasif dan suasana di kelas kurang menyenangkan dikarenakan guru lebih dominan menggunakan metode ceramah dengan model teaching center sehingga berdampak pada hasil belajar yang kurang maksimal yaitu terdapat beberapa hasil belajar siswa kurang dari KKM yang ditentukan 75 berjumlah $40 \%$ dari 24 keseluruhan jumlah siswa. Tujuan penelitian ini adalah (1) Mengetahui penerapan metode talking stick untuk meningkatkan kemampuan handson (2) Mengetahui peningkatan kemampuan hands-on dengan menggunakan metode talking stick. Metode talking stick termasuk salah satu metode pembelajaran yang dilakukan dengan bantuan tongkat, siapa yang memegang tongkat wajib
\end{abstract}


menjawab pertanyaan dari guru setelah siswa mempelajari materi pokok yang diajarkan oleh guru. Pembelajaran dengan metode talking stick sangat cocok diterapkan pada pendidikan Dasar (SD/MI), karena selain melatih kemapuan psikomotor dan kognitif, pembelajaran ini menciptakan suasana yang menyenangkan dan membuat siswa aktif. Metode talking stick ini sangat tepat digunakan dalam pengembangan hands-on. Peneliti yang dilakukan menggunakan pendekatan kualitatif dengan jenis penelitian tindakan kelas (PTK). Teknik yang digunakan dalam pengumpulan data antara lain: observasi, wawancara, dokumentasi, pengukuran tes, dan catatan lapangan. Analisis yang digunakan peneliti menggunakan teknik deskriptif kualitatif. Urutan kegiatan penelitian mencakup 4 tahap meliputi: (1) Perencanaan, (2) Pelaksanaan, (3) Pengamatan, dan (4) Refleksi. Hasil penelitian diperoleh data bahwa adanya peningkatan kemampuan hands-on siswa pembelajaran materi Bangun Ruang pada siswa kelas IV dari 2 siklus yang telah dijalankan serta dapat memenuhi indikator kinerja yang telah ditetapkan. Pada pelaksanaan siklus I pada kemampuan Hands-On siswa dari siklus I ke siklus II juga mengalami peningkatan yaitu pada siklus I jumlah siswa yang mendapat nilai di atas KKM 75 sebanyak 60\% dari 24 jumlah keseluruhan siswa yang hadir dan pada siklus II jumlah siswa yang mendapat nilai di atas KKM mencapai $82 \%$ terdapat peningkatan sebanyak 25\% dari siklus I ke siklus II dengan nilai Rata-Rata kemampuan Hands-On siklus I sejumlah 75,8 dan pada siklus II nilai rata-rata 80,16 peningkatan sebesar 4,36. Berdasarkan hasil analisis data penelitian tersebut dapat disimpulkan bahwa pengunaan metode talking stick dapat meningkatkan kemampuan Hands-On pada materi Bangun Ruang serta pelaksanaannya dapat berjalan dengan efektif dan efesien.

Kata Kunci: hands-on, metode talking stick, bangun ruang

\section{A. Pendahuluan}

Pendidikan merupakan kebutuhan manusia. Pendidikan selalu mengalami perubahan, perkembangan dan perbaikan sesuai dengan perkembangan di segala bidang kehidupan. Perubahan dan perbaikan dalam bidang pendidikan meliputi berbagai komponen yang terlibat di dalamnya baik itu pelaksana pendidikan di lapangan 
(kompetensi guru dan kualitas tenaga pendidik), mutu pendidikan, perangkat kurikulum, sarana dan prasarana pendidikan dan mutu menejemen pendidikan termasuk perubahan dalam metode dan strategi pembelajaran yang lebih inovatif. Upaya perubahan dan perbaikan tersebut bertujuan membawa kualitas pendidikan Indonesia lebih baik.

Mengembangkan metode pengajaran merupakan salah satu upaya untuk meningkatkan kualitas belajar siswa. Metode dalam proses belajar mengajar merupakan sebagai alat untuk mencapai tujuan, perumusan tujuan dengan sejelas-jelasnya merupakan syarat terpenting sebelum seseorang menentukan dan memilih metode mengajar yang tepat. Apabila seorang guru dalam memilih metode mengajar kurang tepat akan menyebabkan kekaburan tujuan yang menyebabkan kesulitan dalam memilih dan menentukan metode yang akan digunakan. (Zuhairini. 1983: 79).

Materi Bangun Ruang merupakan salah satu materi Matematika di SD/MI yang bersifat kongkrit. Oleh karena itu perlu metode pembelajaran yang tepat agar materi Bangun Ruang dapat bermakna bagi siswa.

Pada kenyataannya kegiatan belajar menggajar pembelajaran materi Bangun Ruang di MI Islamiah Dinoyo Terdepan Deket Lamongan terdapat permasalahan diantaranya terlihat siswa cenderung pasif dan suasana di kelas kurang menyenangkan dikarenakan guru lebih dominan menggunakan metode ceramah dengan model teaching center sehingga berdampak pada hasil belajar yang kurang maksimal yaitu terdapat beberapa hasil belajar siswa kurang dari KKM yang ditentukan 75 berjumlah 40\% dari 24 keseluruhan jumlah siswa.

Menerapkan metode pembelajaran merupakan salah satu upaya untuk meningkatkan kualitas belajar siswa. Penggunana metode dalam proses belajar mengajar sebagai salah satu cara untuk mencapai tujuan yang diharapkan secara maksimal. Metode talking stick termasuk salah satu metode pembelajaran yang dilakukan dengan bantuan tongkat, siapa yang memegang tongkat wajib menjawab pertanyaan dari guru setelah siswa mempelajari 
materi pokok yang diajarkan oleh guru. Metode talking stick ini sangat tepat digunakan dalam pengembangan hands-on. Dengan menggunakan metode talking stick, perkembangan psikomotor siswa dapat meningkat, karena menurut Ramadhan, talking stick (tongkat berbicara) adalah metode yang pada mulanya digunakan pleh penduduk asli Amerika untuk mengajak semua orang berbicara atau menyampaikan pendapat dalam suatu forum. tongkat berbicara sering digunakan di kalangan dewan untuk memutuskan siapa yang mempunyai hak berbicara (Nanang Harafiah: 48).

Berdasarkan permasalahan di atas, penting untuk dilakukan penelitian dalam rangka meningkatkan kualitas pembelajaran materi Bangun Ruang dengan judul "Meningkatkan Kemampuan Hands-On Siswa pada Materi Bangun Ruang dengan Menggunakan Metode Talking Stick Kelas IV di MI Islamiah Dinoyo Terdepan Lamongan" dengan tujuan agar hasil belajar siswa dapat meningkat dari yang sebelumnya.

\section{B. Pembahasan}

\section{Pengertian Metode}

Metode berasal dari bahasa Greek yang terdiri dari "Meta" yang berarti jalan yang dilalui (Arifin, 1991). metode dalam pengertian istilah telah banyak dikemukakan oleh pakar dalam dunia pendidikan sebagaimana berikut ini:

a. Prof. Dr. Hasan Langgunung, mengatakan bahwa " Metode adalah suatu cara atau jalan yang dilalui untuk mencaBahasa Arab tujuan pendidikan" (Hasan Langgulung, 1986).

b. Direktoran Pembina PTAI " Metode adalah suatu cara siasat penyampaian bahan pengajaran tertentu dari suatu mata pelajaran agar siswa dapat mengetahui, memahami, mempergunakan dan dengan kata lain menguasai bahan pelajaran tersebut" (Direktorat Pembina PTAI, 1985).

Berdasarkan pendapat di atas dapat ditarik kesimpulan bahwa metode merupakan suatu cara atau alat untuk mencapai tujuan, selain itu metode adalah suatu bagian dari komponen proses pendidikan. 
Oleh karenanya guru harus berusaha semaksimal mungkin didalam menerapkan suatu metode yang nantinya diharapkan dapat mencapai tujuan didalam pengajaran.

\section{Pengertian Metode Pembelajaran}

Metode dianggap sebagai suatu cara yang digunakan untuk mancapai tujuan yang telah ditetapkan. Dalam kegiatan belajar mengajar, metode pembelajaran sangat diperlukan oleh guru, dengan penggunaan yang bervariasi dan sesuai dengan tujuan yang ingin dicapai. Menguasai metode pembelajaran merupakan keniscayaan, sebab seorang guru tidak akan mengajar dengan baik apabila tidak menguasai metode secara tepat. Metode dianggap sebagai cara atau prosedur yang keberhasilannya di dalam belajar atau sebagai alat yang menjadikan mengajar menjadi efektif (Pupuh Faturrohman, 2001).

Menurut Syaiful Bahri Djamarah dan Winarno Surakhmad, mengemukakan bahwa lima macam faktor yang mempengaruhi penggunaan metode pembelajaran yaitu :

a. Tujuan dengan berbagai jenis dan fungsinya.

b. Anak didik dengan berbagai tingkat kematangannya.

c. Situasi berlainan keadaannya.

d. Fasilitas secara bervariasi secara kualitas dan kuantitasnya.

e. Kepribadian dan kompetensi guru yang berbeda-beda.

Macam-macam metode pembelajaran di antaranya sebagai berikut :

a. Metode ceramah

b. Metode diskusi

c. Metode demonstrasi

d. Metode Talking Stick

e. Metode resitasi

f. Metode jigsaw

g. Problem solving method

h. Metode think pair share 


\section{Metode Talking stick}

\section{a. Metode tim game tournament}

Menurut Ramadhan, talking stick (tongkat berbicara) adalah metode yang pada mulanya digunakan oleh penduduk asli Amerika untuk mengajak semua orang berbicara atau menyampaikan pendapat dalam suatu forum. Tongkat berbicara sering digunakan di kalangan dewan untuk memutuskan siapa yang mempunyai hak berbicara. Tongkat akan berpindah ke orang lain apabila ia ingin berbicara atau menanggapinya. Dengan cara ini tongkat berbicara akan berpindah dari satru orang ke orang lain jika orang tersebut ingin mengemukakan pendapatnya. Apabila semua mendapatkan giliran berbicara, tongkat itu lalu dikembalikan lagi ke ketua/ pimpinan rapat.

Penjelasan di atas, dapat disimpulkan bahwa Metode talking stick termasuk salah satu metode pembelajaran yang dilakukan dengan bantuan tongkat, siapa yang memegang tongkat wajib menjawab pertanyaan dari guru setelah siswa mempelajari materi pokoknya. Pembelajaran talking stick sangat cocok diterapkan di $\mathrm{SD}$, karena selain melatih kemapuan psikomotor dan kognitif, pembelajaran ini menciptakan suasana yang menyenangkan dan membuat siswa aktif.

Suprijono mengatakan bahwa, "Metode talking stick mendorong peserta didik untuk berani mengemukakan pendapat". Metode talking stick ini sangat tepat digunakan dalam pengembangan mindson dan hands-on (Nanang: 48).

\section{b. Langkah-Langkah Metode Talking Stick}

1. Guru menyiapkan sebuah tongkat.

2. Guru menyampaikan materi pokok yang akan dipelajari secara singkat, kemudian memberikan kesempatan kepada peserta didik untuk membaca dan mempelajari materi pegangannya.

3. Setelah selesai membaca buku dan mempelajarinya, peserta didik dipersilahkan untuk menutup bukunya. 
4. Guru mengambil tongkat dan memberikan kepada siswa, setelah itu guru memberikan pertanyaan dan siswa yang memegang tongkat tersebut harus menjawabnya dan seterusnya, sampai sebagian besar siswa mendapat bagian untuk menjawab setiap pertanyaan guru.

5. Siswa yang berhasil menyelesaikan soalnya dengan menjawab dengan baik akan mendapatkan smile tag dari guru.

6. Guru memberikan kesimpulan dan tambahan jawaban yang kurang benar dari siswa.

7. Evaluasi

8. Penutup.

\section{Kajian Bangun Ruang}

\section{a. Pengertian Bangun Ruang}

Bangun ruang adalah bagian ruang yang dibatasi oleh himpunan titik-titik yang terdapat pada seluruh permukaan bangun tersebut. Permukaan bangun itu disebut sisi.

Dalam memilih model untuk permukaan atau sisi, sebaiknya guru menggunakan model berongga yang tidak transparan. Model untuk bola lebih baik digunakan sebuah bola sepak dan bukan bola bekel yang pejal, sedangkan model bagi sisi balok lebih baik digunakan kotak kosong dan bukan balok kayu. Hal ini mempunyai maksud untuk menunjukkan bahwa yang dimaksud sisi bangun ruang adalah himpunan titik-titik yang terdapat pada permukaan atau yang membatasi suatu bangun ruang tersebut. Selain itu bangun ruang dengan model berongga yang transparan ini juga dapat untuk melatih siswa dalam menggambar bangun ruang, karena kedudukan semua unsur bangun ruang dapat diamati untuk dialihkan dalam gambar (Agus Suharja, 2008)

\section{b. Bentuk-Bentuk Bangun Ruang}

Bentuk-bentuk bangun ruang yang terdapat pada materi bangun ruang diantaranya sebagai berikut (Agus Suharja, 2008):

1. Bola

2. Tabung 

3. Kubus
4. Balok
5. Limas
6. Kerucut
7. Prisma

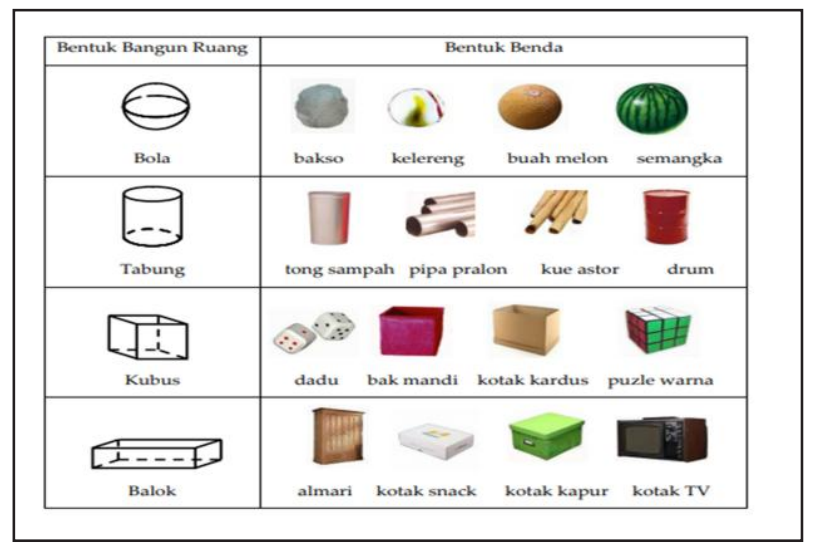

\section{Gambar 2.1 Bentuk Bangun Ruang}

\section{Kemampuan Hands-on}

Kemampuan hands-on (disebut juga psikomotor) merupakan kemampuan yang progresif dan berhubungan dengan perolehan aneka ragam ketrampilan fisik anak (motor skill). Menurut Howe, hal ini mengingat pola-pola gerakan yang cakap dan terkoordinasi itu tak dapat mencapai dengan baik semata-mata dengan mekanisme sederhana, tetapi dengan menggunakan proses mental yang sangat kompleks (Desmita, 2009).

\section{Metode Penelitian}

\section{a. Rancangan Penelitian}

Penelitian ini dirancang dengan menggunakan pendekatan penelitian kualitatif dengan jenis Penelitian Tindakan Kelas (PTK/ classroom action research) yakni suatu penelitian yang mengkaji proses pembelajaran dikaitkan dengan pengoptimalan penggunaan metode, media, strategi pembelajaran, di mana kegiatan perbaikan 
pembelajaran tersebut diharapkan dapat meningkatkan proses dan hasil pembelajaran siswa. PTK juga bertujuan untuk memberikan sumbangan nyata bagi peningkatan profesionalisme, menyiapkan pengetahuan, pemahaman, dan wawasan tentang perilaku guru mengajar dan murid belajar (Suharsimi Arikunto dkk, 2007).

Dalam penelitian tindakan kelas ini, peneliti melaksanakan melalui dua siklus yaitu siklus I dengan 3 kali pertemuan dan siklus II juga 3 kali pertemuan. Rancangan PTK yang digunakan pada penelitian ini menggunakan model spiral penelitian tindakan kelas dari Arikunto yang meliputi 4 tahap perencanaan, pelaksanaan tindakan, observasi, dan refleksi.

\section{b. Subyek Penelitian}

Dalam Penelitian Tindakan Kelas ini yang menjadi subjek penelitian adalah siswa kelas IV MI Islamiyah Dinoyo Terdepan Deket Lamongan Tahun Ajaran 2019/2020 yang terdiri dari 24 siswa.

\section{c. Waktu dan Lokasi Penelitian}

Penelitian ini dilakukan mulai bulan Mei 2019 dan dilaksanakan di MI Islamiah Dinoyo Terdepan Deket Kabupaten Lamongan karena kemampuan Hands-on siswa rendah pada pembelajaran materi Bangun Ruang.

\section{d. Data dan Sumber Data}

Pada penelitian kali ini yang dijadikan subyek penelitian adalah siswa kelas IV di MI Islamiyah Dinoyo Terdepan Deket Lamongan, di mana siswa menjadi subyek penelitian dan juga aktif dalam kegiatan yang dilakukan. Berikut data dan sumber data yang peneliti gunakan :

Tabel 3.1 Sumber dan Jenis Data

\begin{tabular}{clc}
\hline No. & \multicolumn{1}{c}{ Jenis Data } & Sumber Data \\
\hline 1. & Hasil tes awal dan tes akhir. & Siswa \\
\hline 2. & $\begin{array}{l}\text { Wawancara tentang langkah-langkah } \\
\text { pembelajaran yang biasa digunakan di kelas. }\end{array}$ & Guru \\
\hline $\begin{array}{l}\text { Aktivitas antara guru dan siswa selama } \\
\text { proses pembelajaran. }\end{array}$ & Guru dan Siswa \\
\hline
\end{tabular}




\section{e. Teknik Pengumpulan Data}

Data yang akurat akan bisa diperoleh ketika proses pengumpulan data tersebut dipersiapkan dengan matang. Dalam penelitian ini akan digunakan beberapa cara untuk mengumpulkan data selama proses penelitian (Pupuh Faturrohman dan M. Sobry Sutikno, 2001). Teknik pengumpulan data yang digunakan peneliti dalam penelitian tindakan kelas meliputi;

1. Observasi

2. Wawancara

3. Tes individu dan kelompok

4. Angket

5. Dokumentasi

\section{f. Analisis Data}

Nasution menyatakan bahwa analisis adalah pekerjaan yang sangat sulit, memerlukan kerja keras. Analisis memerlukan daya kreatif serta kemampuan intelektual yang tinggi. Tidak ada cara tertentu yang dapat diikuti untuk mengadakan analisis, sehingga setiap peneliti harus mencari sendiri metode yang dirasakan cocok dengan sifat penelitiannya. Bahan yang sama bisa diklasifikasikan lain oleh peneliti yang berbeda (Lexy J. Moleong, 1996).

Analisis data kualitatif yang dikutip oleh Moleong adalah upaya yang akan dilakukan dengan jalan bekerja dengan data, mengorganisasikan data, memilah-milahnya menjadi satuan yang dapat dikelola, mensintesiskannya, mencari dan menemukan pola, menemukan apa yang penting dan apa yang dipelajari, dan memutuskan apa yang dapat diceritakan kepada orang lain (Lexy J. Moleong, 1996).

Data yang diperoleh dari tindakan dianalisis dengan teknik analisis deskriptif kualitatif untuk memastikan bahwa dengan mengaplikasikan metode talking stick dapat meningkatkan kemampuan minds-on dan hands-on siswa. Data yang bersifat kualitatif, terdiri dari hasil observasi, wawancara, dan dokumentasi dianalisis secara kualitatif. Sedangkan data yang dikumpulkan berupa angka 
atau data kuantitatif cukup dengan menggunakan analisis deskriptif dan sajian visual. Sajian tersebut untuk menggambarkan bahwa dengan tindakan yang akan dilakukan dapat menimbulkan adanya perbaikan, peningkatan, atau perubahan ke arah yang lebih baik, jika dibandingkan dengan keadaan sebelumnya. Proses analisis data yang dilakukan oleh peneliti yaitu dengan langkah-langkah sebagai beikut:

1. Reduksi Data

2. Display data atau penyajian data

3. Menarik kesimpulan atau verifikasi

\section{Paparan Hasil Penelitian}

Pada penelitian tindakan kelas (PTK) ini dilakukan sebanyak 2 siklus dengan 6 kali pertemuan yaitu siklus I dengan 3 kali pertemuan dan siklus II 3 kali pertemuan masing-masing pertemuan sebanyak ( 2 x 35 menit) dengan mengambil materi pokok Bangun Ruang Sederhana dan sifat-sifatnya. Adapun langkah-langkah tindakan pada tiap siklus dibagi menjadi beberapa langkah yaitu: (1) perencanaan (planning), (2) pelaksanaan (acting), (3) pengamatan (observating), dan (4) refleksi (reflecting).

\section{a. Hasil Penelitian Siklus I}

Pada siklus I dilaksanakan sebanyak 3 kali pertemuan.

1. Pertemuan 1

Pertemuan pertama dilaksanakan pada hari Kamis tanggal 18 Juli 2019 peneliti menetapkan pembelajaran sebanyak (1 x 35 menit) dengan mengambil materi pokok Bangun Ruang Sederhana dengan indikator siswa menyebutkan macam-macam jenis bangunubungkan dengan benda di sekitarnya ruang (Kubus dan Balok).

2. Pertemuan 2

Pertemuan kedua dilaksanakan pada hari Sabtu tanggal 20 Juli 2019 peneliti menetapkan pembelajaran sebanyak (1 x 35 menit) dengan mengambil materi pokok Bangun 
Ruang Sederhana dengan indikator Mengidentifikasi sifatsifat bangun ruang Kubus dan Balok dan menghubungkan dengan benda kongkrit di sekitar.

3. Pertemuan 3

Pertemuan ketiga dilaksanakan pada hari Selasa tanggal 23 Juli 2019 peneliti menetapkan pembelajaran sebanyak (1 x 35 menit) dengan mengambil materi pokok Bangun Ruang Sederhana dengan indikator Menggambar jenis-jenis bangun ruang Kubus dan Balok.

Pada siklus 1 pertemuan pertama berhasil meski belum memenuhi target ketuntasan belajar pada materi pengenalan bangun ruang. Berdasarkan siklus 1 kegiatan pembelajaran berjalan dengan lancar. Setiap siswa mengikuti pembelajaran dengan serius. Siswa mengikuti penjelasan pelajaran Matematika dan mengerjakan tugasnya dengan penuh semangat. Suasana di kelas menjadi hidup (aktif) dan menyenangkan.

Pada pertemuan pertama tersebut nilai siswa lumayan baik, walaupun nilai beberapa siswa belum sesuai KKM yang ditetapkan MI Islamiyah Dinoyo Terdepan yakni 75 . Bahkan beberapa siswa masih ada yang mendapatkan nilai rendah yakni 60 . Siswa yang mendapatkan nilai rendah ini memang siswa yang kurang memperhatikan guru saat mengajar.

\section{b. Hasil Penelitian Siklus II}

Pada siklus I dilaksanakan sebanyak 3 kali pertemuan.

1. Pertemuan 1

Pertemuan pertama dilaksanakan pada hari Kamis 25 Juli 2019 ini peneliti menetapkan pembelajaran sebanyak (1 x 35 menit) dengan mengambil materi pokok Bangun Ruang Sederhana dengan indikator menyebutkan macam-macam jenis bangun ruang (Tabung dan Bola) dan menghubungkan pada benda kongkrit yang ada di sekitar. 


\section{Pertemuan 2}

Pertemuan kedua dilaksanakan pada hari Sabtu tanggal 27 Juli 2019 peneliti menetapkan pembelajaran sebanyak (1 x 35 menit) dengan mengambil materi pokok Bangun Ruang Sederhana dengan indikator Mengidentifikasi sifat-sifat bangun ruang Tabung dan Bola.

3. Pertemuan 3

Pertemuan ketiga dilaksanakan pada hari Selasa tanggal 30 Juli 2019 peneliti menetapkan pembelajaran sebanyak (1 x 35 menit) dengan mengambil materi pokok Bangun Ruang Sederhana dengan indikator Menggambar jenis-jenis bangun ruang Tabung dan Bola.

Pada siklus II pertemuan pertama terdapat 3 siswa yang kurang memenuhi target ketuntasan belajar pada materi pengenalan bangun ruang. Berdasarkan siklus II kegiatan pembelajaran berjalan dengan lancar. Setiap siswa mengikuti pembelajaran dengan serius. Siswa mengikuti penjelasan pelajaran Bangun Ruang dan mengerjakan tugasnya dengan penuh semangat. Suasana di kelas menjadi hidup (aktif) dan menyenangkan.

Pada pertemuan pertama sampai ke-3 nilai siswa semakin meningkat, walaupun nilai beberapa siswa belum sesuai KKM yang ditetapkan MI Islamiyah Dinoyo Terdepan yakni 75. Terdapat beberapa siswa masih ada yang mendapatkan nilai rendah yakni 68. Siswa yang mendapatkan nilai rendah ini memang siswa yang kurang fokus dalam pembelajaran.

Tabel. 3.3 Hasil Kemampuan Hans-On Siswa siklus I dan siklus II

\begin{tabular}{cccc}
\hline No & Identitas Siswa & SIKLUS I & SIKLUS II \\
\hline 1 & ADN & 78 & 72 \\
\hline 2 & MIA & 70 & 82 \\
\hline 3 & DAH & 80 & 86 \\
\hline 4 & KJL & 80 & 82 \\
\hline 5 & HFG & 82 & 78 \\
\hline
\end{tabular}




\begin{tabular}{cccc}
\hline 6 & ERW & 78 & 70 \\
\hline 7 & TAD & 72 & 75 \\
\hline 8 & MCS & 70 & 87 \\
\hline 9 & AAF & 84 & 85 \\
\hline 10 & SRT & 82 & 82 \\
\hline 11 & DEL & 80 & 78 \\
\hline 12 & KLJ & 67 & 70 \\
\hline 13 & AWH & 68 & 72 \\
\hline 14 & DCA & 70 & 80 \\
\hline 15 & ZTR & 80 & 83 \\
\hline 16 & UHM & 85 & 86 \\
\hline 17 & TYH & 80 & 87 \\
\hline 18 & SIN & 78 & 85 \\
\hline 19 & PEB & 72 & 73 \\
\hline 20 & IKD & 60 & 78 \\
\hline 21 & JDH & 83 & 86 \\
\hline 22 & MDL & 68 & 80 \\
\hline 23 & TSA & 74 & 82 \\
\hline 24 & MSZ & 78 & 85 \\
\hline & Nilai rata-rata & 75,8 & $\mathbf{8 0 , 1 6}$ \\
\hline
\end{tabular}

Berdasarkan uraian di atas terkait dengan penggunaan Metode Talking Stick dapat meningkatkan kemampuan Hans-On siswa terbukti melalui hasil penilaian belajar materi Bangun ruang baik siklus I dan siklus II Hans-On pada siklus I sejumlah 75,8 dibanding dengan nilai Hans-On pada siklus II sejumlah 80,16.

\section{Analisis Penerapan Metode Talking Stick Materi Bangun Ruang Kelas IV di MI Islamiah Dinoyo Terdepan Deket Lamongan}

Metode talking stick termasuk salah satu metode pembelajaran yang dilakukan dengan bantuan tongkat, siapa yang memegang tongkat wajib menjawab pertanyaan dari guru setelah siswa mempelajari materi pokoknya. Pembelajaran talking stick sangat cocok diterapkan di SD, karena selain melatih kemapuan psikomotor dan kognitif, pembelajaran ini menciptakan suasana yang menyenangkan dan membuat siswa aktif (Nanang Harafiah dan Cucu Suhana:48). 
Langkah-langkah yang dapat dilakukan dalam model pembelajaran ini sebagai berikut: 1) Guru menyiapkan sebuah tongkat; 2) Guru menyampaikan materi pokok yang akan dipelajari secara singkat, kemudian memberikan kesempatan kepada peserta didik untuk membaca dan mempelajari materi pegangannya; 3) siswa dipersilahkan untuk menutup bukunya; 4) Guru mengambil tongkat dan memberikan kepada siswa, setelah itu guru memberikan pertanyaan dan siswa yang memegang tongkat tersebut harus menjawabnya.

Hasil penelitian menunjukkan bahwasanya penerapan metode Talking Stick dapat dikatakan efektif dan efisien menimbulkan antusias siswa hal ini terbukti pada siklus I yang dilakukan sebanyak 3 kali pertemuan pada tanggal 18, 20, dan 23 Juli 2019. Dapat diketahui bahwa awalnya masih banyak siswa yang merasa bingung dengan materi meski sudah diterangkan oleh guru dengan menggunakan metode talking stick. Hal ini dikarenakan siswa baru pertama kali melakukan metode yang baru diterapkan di sekolah mereka. Pada siklus I dirancang untuk memberikan pemahaman materi Bangun Ruang Sederhana dan sifat-sifatnya yaitu bangun ruang Kubus dan Balok kepada siswa dengan menggunakan metode talking stick. Pada materi ini siswa masih merasa kesulitan untuk menjelaskan sifatsifat bangun ruang Kubus dan Balok. Namun pada pertemuan ke-2 dan ke-3 pada siklus I kemampuan siswa hands-on siswa semakin meningkat dan semangat anak mulai tumbuh.

Pada pelaksanaan siklus II yang dilaksanakan 3 kali pertemuan pada 25, 27 dan 30 Juli 2019 dapat diketahui bahwa kondisi pembelajaran bisa lebih baik lagi karena siswa sudah terbiasa dengan metode talking stick dan siswa merasa senang jika berdiskusi dengan teman. Kelompok belajar ini tidak ada perbedaan antara siswa yang pandai dan kurang pandai karena setiap kelompok belajar dibentuk secara acak. Selain itu guru telah melaksanakan kegiatan pembelajaran sesuai dengan perencanaan pada rencana pelaksanaan pembelajaran (RPP) bersama peneliti. Pada siklus II ini, mulai terjadinya peningkatan kemampuan hands-on yang diperoleh oleh setiap kelompok. Setiap kelompok sudah mulai 
saling bekerjasama, lebih aktif bertanya, dan menjawab pertanyaan yang diajukan baik dari guru maupun siswa sendiri.

9. Analisis Peningkatan Kemampuan Hands-On siswa Materi Bangun Ruang dengan menggunakan Metode Talking stick Kelas IV di MI Islamiah Dinoyo Terdepan Deket Lamongan

Kemampuan hands-on (disebut juga psikomotor) merupakan kemampuan yang progresif dan berhubungan dengan perolehan aneka ragam ketrampilan fisik anak (motor skill). Menurut Howe, hal ini mengingat pola-pola gerakan yang cakap dan terkoordinasi itu tak dapat mencapai dengan baik semata-mata dengan mekanisme sederhana, tetapi dengan menggunakan proses mental yang sangat kompleks (Desmita: 67).

Hasil penelitian menunjukkan bahwasanya penggunaan metode Talking Stick dapat meningkatkan kemampuan Hands-On siswa Materi Bangun Ruang di MI Islamiyah Dinoyo Terdepan Deket Lamongan secara signifikan. Hal ini terbukti Pada pelaksanaan siklus I kemampuan Hands-On siswa dari siklus I ke siklus II juga mengalami peningkatan yaitu pada siklus I jumlah siswa yang mendapat nilai di atas KKM 75 sebanyak 60\% dari 24 jumlah keseluruhan siswa yang hadir dan pada siklus II jumlah siswa yang mendapat nilai di atas KKM mencapai $82 \%$ terdapat peningkatan sebanyak 25\% dari siklus I ke siklus II dengan nilai Rata-Rata kemampuan Hands-On siklus I sejumlah 75,8 dan pada siklus II nilai rata-rata 80,16 peningkatan sebesar 4,36. Berdasarkan hasil analisis data penelitian tersebut dapat disimpulkan bahwa pengunaan metode talking stick dapat meningkatkan kemampuan hands-on pada materi Bangun Ruang serta pelaksanaannya dapat berjalan dengan efektif dan efesien.

\section{Penutup}

\section{Simpulan}

Berdasarkan pemaparan hasil penelitian dan pembahahasan di atas dapat disimpulkan beberapa hal berkaitan dengan penggunaan metode Talking Stick terhadap kemampuan Hans-On sebagai berikut: 
a. Penerapan metode Talking Stick pada Materi Bangun Ruang Kelas IV di MI Islamiah Dinoyo Terdepan Deket Lamongan menunjukkan bahwasanya penerapan metode Talking Stick pada tahap I dapat dikatakan efektif dan efisien menimbulkan antusias siswa, dan pada pelaksanaan siklus II dapat diketahui bahwa kondisi pembelajaran bisa lebih baik lagi karena siswa sudah terbiasa dengan metode talking stick dan siswa merasa senang jika berdiskusi dengan teman.

b. Hasil penelitian menunjukkan bahwasanya penggunaan metode Talking Stick dapat meningkatkan kemampuan Hands-On siswa Materi Bangun Ruang di MI Islamiyah Dinoyo Terdepan Deket Lamongan secara signifikan.

\section{Saran}

Metode pembelajaran talking stick yang menempatkan siswa untuk aktif menemukan pengetahuan telah terbukti dapat meingkatkan kemampuan hands-on siswa dan kualitas belajarnya. Untuk itu hendaknya para guru lebih banyak berfikir tentang model, media, dan strategi pembelajaran apa yang mesti diterapkan untuk mencapai kompetensi dasar dan indikator yang ditetapkan. Dengan demikian pemahaman tentang berbagai model, media, dan strategi pembelajaran hendaknya lebih ditingkatkan. Melihat hasil penelitian di atas, maka sebagai saran dari peneliti yang di harapkan dapat menjadi bahan pertimbangan bagi peningkatan mutu pendidikan. 


\section{DAFTAR PUSTAKA}

Abdurrahman, Mulyono. Pendidikan bagi Anak Berkesulitan Belajar. Jakarta: Rineka Cipta, 2005

Al-Quran Digital, Surat Al-Baqoroh ayat 148

Arikunto, Suharsimi dkk. Penelitian Tindakan Kelas. Jakarta: Bumi Aksara, 2007

Bodgan, Robert, Steven J. Taylor. Kualitaif; Dasar-dasar Penelitian. terj., A. Khozin Afandi. Surabaya: Usaha Nasional, 1993

Departemen Agama RI. Al-Qur'an dan Terjemahanya. Jakarta: Proyek Pengadaan Kitab Suci Al-Qur'an Dept. Agama RI, 1982

Departemen Pendidikan Nasional. Standar Kompetensi Mata Pelajaran Kls. I s.d. VI Sekolah Dasar dan Madrasah Ibtidaiyah. Jakarta: Departemen Pendidikan Nasional, 2004

Desmita. Psikologi Perkembangn Peserta Didik. Bandung: PT Remaja Rosdakarya, 2009

Faturrohman, Pupuh dan Sutikno, Sobry. Strategi Belajar Mengajar melalui Pendekatan Penanaman Konsep Umum dan Islami. Jakarta: Refika Aditama, 2001

Ghony, Djunaidi. Penelitian Tindakan Kelas. Malang: UIN-Malang Press, 2008

Gufron, A. Kurikulum Berbasic Kompetensi di Perguruan Tinggi: Prinsip dan Langkah-langkah Pengembangan. Yogyakarta, 2004

Hadis, Abdul. Psikologi dalam Pendidikan. Bandung: Alfabeta, 2006

Hamzah. Mengelola Kecamatanerdasan dalam Pembelajaran. Jakarta; Bumi Aksara, 2009

Harafiah, Nanang dan Suhana, Cucu. Konsep Strategi Pembelajran. Bandung: Refika Aditama

http:www.wikipedia.org/wiki/Matematika\#.3F.com.Apakahmatematika? diakses 21 mei 2012

Hudojo, Herman. Strategi Mengajar Belajar Matematika. Malang: IKIP Malang, 1988

Iskandar. Psikologi Pendidikan. Cipayung: Gaung Persada Press

Elementary Vol. 7 No. 2 Juli-Desember 2019 
Moleong, J, Lexy. 1996. Metodologi Penelitian Kualitatif. Bandung: PT Remaja Rosdakarya

Mulyasa. Manajeman Berbasis Sekolah. Bandung: PT Remaja Rosdakarya, 2007

Ni'am, Syamsun, M. Implementasi Pembelajaran Berbasis Multiple Intelligences Dalam Meningkatkan Kreativitas Dan Hasil Belajar Siswa Pada Mata Pelajaran ,Pendidikan Agama Islam Kelas III Di MIN Beji Pasuruan, Skripsi, Jurusan Pendidikan Agama Islam, Fakultas Tarbiyah, Universitas Islam Negeri Maulana Malik Ibrahim Malang, 2009

Sadili, Hasan. Ensiklopedi Indonesia. Jakarta: Ichtiar Baru Van Houve Sanjaya, Wina. Strategi Pembelajaran Berorientasi Standart Proses Pendidikan. Jakarta: Kencana, 2007

Sukmadinata. Syaodih. Nana. Metode Penelitian Pendidikan. Bandung: PT Remaja Rosdakarya, 2007

Susanto, Ahmad. Perkembangan Anak Usia Dini Pengantar dalam Berbagai Aspeknya, Jakarta: Kencana Perdana Media Group, 2011

Syah, Muhibbin. Psikologi Pendidikan dengan Pendekatan Baru. Bandung: PT Remaja Rosdakarya, 1995

Syarif, Muhammad. Strategi Pembelajaran, Jakarta: Rajagrafindo Persada, 2015

Tim Penyusun Kamus Pusat Pembinaan dan Pengembangan Bahasa. Kamus Besar Bahasa Indonesia. Jakarta: Balai Pustaka, 1996

Wahidmurni. Penelitan Tindakan Kelas Dari Teori Menuju Praktik. Malang: UM PRESS, 2008 